\title{
ANALISIS PENGARUH MACROBENDING SERAT OPTIK PADA SENSOR GLUKOSA DENGAN METODE EVANESCENT
}

\author{
Nola Fridayanti, Muldarisnur Muldarisnur *, Harmadi Harmadi \\ Jurusan Fisika Universitas Andalas \\ *Korespondensi ke: mrisnur@gmail.com
}

( Diterima:15 Februari 2018; Direvisi: 21 Februari 2018; Diterbitkan: 01 Maret 2018)

\begin{abstract}
ABSTRAK
Telah dilakukan analisis pengaruh macrobending serat optik yang telah dikupas claddingnya sepanjang $1 \mathrm{~cm}$ pada sensor glukosa dengan memanfaatkan interaksi gelombang evanescent pada serat optik dengan molekul glukosa. Cahaya dari laser dioda dengan panjang gelombang $650 \mathrm{~nm}$ ditransmisikan pada serat optik multimode. Pengupasan sebagian cladding serat mengakibatkan pelemahan intensitas terukur pada detektor akibat interaksi gelombang evanescent dengan molekul glukosa dalam urine. Penurunan intensitas cahaya terukur sebagai perubahan tegangan pada fotodioda yang mengindikasikan kosentrasi glukosa. Perbedaan konsentrasi glukosa berkaitan dengan indeks bias larutan glukosa $\left(\mathrm{n}_{2}\right)$ yang menentukan kuat interaksi dan pelemahan gelombang evanescent. Intensitas cahaya yang sampai ke detektor meluruh secara eksponensial sebagai fungsi dari panjang pengupasan cladding serat optik. Hasil pengukuran menunjukkan bahwa tegangan keluaran dari sensor berkurang secara linear terhadap konsentrasi glukosa dengan sensitivitas yang diperoleh adalah $0,32558(\mathrm{mg} / \mathrm{dl}) / \mathrm{mV}, 0,34193(\mathrm{mg} / \mathrm{dL}) / \mathrm{mV}$, dan 0,33677 $(\mathrm{mg} / \mathrm{dL}) / \mathrm{mV}$.

Kata kunci: macrobending, gelombang evanescent, serat optik, glukosa.
\end{abstract}

\section{ABSTRACT}

A optical fiber optic with length of cladding stripping of $1 \mathrm{~cm}$ macrobending of effect on glucose sensors by utilizing the interaction of evanescent waves in optical fibers with glucose molecules has been performed. The method employs the interaction of evanescent field that leaks out of fiber optic core to probe the glucose. Light with a wavelength of $650 \mathrm{~nm}$ from laser diode was transmitted through a multimode fiber. The partial removal of fiber cladding allows interaction of evanescent wave with glucose molecules. The interaction causes decay in guided light intensity arriving at photodiode. Different glucose levels correspond to different refractive index. The refractive index determines the interaction strength and therefore the decay of the detected light. The detected light intensity decays exponentially with the length of cladding removal. The measurement shows that the output voltage of the sensor decreases linearly with the concentration of glucose with a sensitivity of $0,32558(\mathrm{mg} / \mathrm{dl}) / \mathrm{mV}, 0,34193(\mathrm{mg} / \mathrm{dL}) / \mathrm{mV}$, dan 0,33677 $(\mathrm{mg} / \mathrm{dL}) / \mathrm{mV}$.

Keywords:macrobending, evanescent wave, fiber optic, glucose.. 


\section{PENDAHULUAN}

Diabetes Mellitus (DM) atau biasa disingkat diabetes merupakan gangguan metabolik menahun akibat pankreas tidak memproduksi cukup insulin atau tubuh tidak merespon insulin yang dihasilkan (America Diabetes Association, 2012). Kementerian Kesehatan Indonesia (INFODATIN, 2014) pada tahun 2013 menemukan bahwa sekitar 12.191.464 juta penduduk Indonesia menderita diabetes. Pertumbuhan penderita diabetes di Indonesia sangat tinggi dan diperkirakan akan mencapai lebih dari 21 Juta penderita pada tahun 2030. Diabetes susah untuk disembuhkan, yang dapat dilakukan hanyalah pengontrolan kadar gula darah untuk menjaga agar tubuh tetap sehat (Said dkk., 2016).

Pengontrolan kadar gula darah tersebut biasanya dilakukan dengan menusuk jari atau lengan penderita untuk mengambil sampel darah. Seorang penderita diabetes melakukan minimal 4 kali monitoring dalam sehari, dimana satu kali pengujian membutuhkan waktu sekitar 2 jam. Penusukkan jari atau lengan saat pengujian kadar gula darah mengakibatkan infeksi. Infeksi disebabkan penderita diabetes tidak dapat memproduksi insulin dalam tubuhnya. Insulin memiliki peran penting dalam penyerapan dan pengontrolan gula dalam sel-sel tubuh untuk menghasilkan energi (Said dkk., 2016). Kekurangan energi pada bagian yang luka atau sel yang rusak akan menghambat penyembuhan bahkan menyebabkan infeksi (Jhon, 2011).

Besarnya efek samping bagi tubuh menandakan bahwa penentuan kadar gula darah dengan pengambilan darah tidaklah efektif. Oleh karena itu, diperlukan metode alternatif yang bersifat non-invasive (tidak merusak) untuk menentukan kadar gula darah dengan menggunakan cairan tubuh lain seperti urine (Sorvoja dan Risto, 2006). Urine sangat potensial digunakan untuk pemantauan kadar gula darah karena sangat mudah dikumpulkan dan mengandung informasi tentang metabolisme tubuh (Bhumika dkk., 2015). Penentuan glukosa darah melalui urine sangat potensial sekali untuk dikembangkan, untuk itu diperlukan sensor glukosa dalam proses pengukuran glukosa darah.

Penentuan kadar gula darah dengan metode optik telah dilakukan oleh para peneliti. Menurut Irawati (2012) metode optik dengan menggunakan serat optik dapat dijadikan metode alternatif dalam mengukur kadar gula darah secara non-invasive. Serat optik telah banyak dikembangkan dalam penentuan kadar gula darah dan mengatasi keterbatasan teknik sebelumnya (Davies dkk., 2006). Pengukuran kadar gula darah secara in-vivo juga telah dilakukan (Ozaki, dalam Tuchin, 2009). Namun, penelitian oleh para peneliti sebelumnya tersebut masih menggunakan sampel darah sehingga dapat menyakiti penderita diabetes yang rentan terhadap luka di kulit. Pemanfaatan serat optik juga pernah dilakukan sebelumnya dalam penentuan kadar glukosa murni (Binu dkk., 2008).

Pada penelitian ini telah dikembangkan dan dianalisis sensor glukosa dengan memanfaatkan pelemahan cahaya akibat interaksi gelombang evanescent dengan molekul glukosa di dalam larutan. Tegangan keluaran fotodioda berkurang secara linear terhadap konsentrasi glukosa. Sampel yang digunakan adalah glukosa murni yang dilarutkan dengan aquades. 
Interaksi antara konsentrasi glukosa dengan serat optik berupa absorpsi gelombang evanescent pada bagian serat optik yang dikelupas. Peluruhan medan evanescent dari bidang batas core dan cladding serat optik ke dalam larutan glukosa dapat dilihat pada Gambar1.

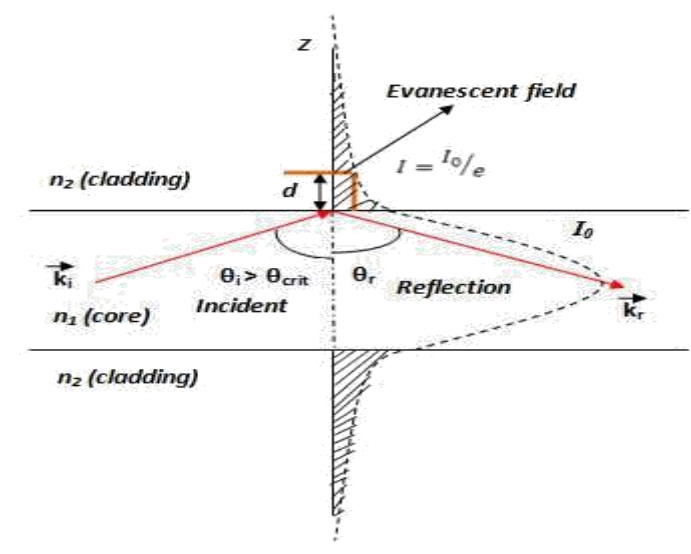

Gambar 1. Gelombang Evanescent

Gelombang evanescent merupakan gelombang berdiri yang menembus ke dalam cladding dan merambat sepanjang bidang batas serat optik. Gelombang evanescent muncul akibat tumpang tindih antara berkas datang dengan berkas cahaya refleksi internal total pada batas core dan cladding. Gelombang evanescent dapat menembus suatu jarak yang signifikan ketika cladding serat optik dikelupas. Jarak tembus cahaya dikenal sebagai penetration depth yang bergantung pada indeks bias core dan cladding, panjang gelombang cahaya, dan sudut datang $\left(\theta_{i}\right)$ terhadap bidang batas core dengan cladding.

Sensor serat optik yang dirancang dalam penelitian ini, panjang bagian cladding termodifikasi yaitu $1 \mathrm{~cm}$, dengan demikian perubaan intensitas yang ditransmisikan melalui serat optik hanya bergantung pada perubahan indeks absorpsivitas bagian cladding modifikasi akibat tingkat konsentrasi glukosa. Prinsip kerja serat optik sebagai sensor glukosa ini berdasarkan pada absorpsi gelombang evanescent pada antar muka core serat optik. Menurut Maddu (2007) perubahan nilai indeks bias cladding yang dimodifikasi akan menentukan intensitas gelombang evanescent yang terserap. Hal ini juga akan menentukan intensitas gelombang cahaya yang ditransmisikan di dalam core serat optik. Dengan kata lain, perubahan konsentrasi glukosa sebagai cladding akan menentukan gelombang evanescent yang terserap sehingga intensitas cahaya yang dideteksi fotodioda juga akan berubah.

\section{METODE PENELITIAN}

Alat dan bahan yang digunakan dalam pembuatan alat ukur dan persiapan sampel adalah: serat optik multimode step index tipe FD-620-10, fotodioda, Laser 650 $\mathrm{nm}$, larutan aceton, glukosa murni, aquades, multimeter, catu daya, LCD, gelas kimia, dan pipet tetes.

Sistem sensor serat optik dibuat dengan langkah sebagai berikut: (1) pengupasan cladding serat optik, (2) pembuatan larutan glukosa induk dan larutan glukosa anak (3) Pengujian sensitivitas sensor serat optik.Seratoptik sepanjang $21 \mathrm{~cm}$ dikupas bagian tengahnya sepanjang $1 \mathrm{~cm}$. Bagian jaket serat optik dikupas dengan pisau cutter, lalu cladding serat optik digosok dengan tissue yang sudah 48 DOI: $\underline{10.25077 / \text { jif.10.1.46-52.2018 }}$ 
dibasahi larutan acetone, setelah itu diamplas menggunakan amplas halus. Indikasi cladding sudah terkupas adalah cahaya laser yang dilalui ke dalam serat optik dapat terlihat di bagian cladding yang dikupas.

Larutan induk glukosa dibuat dengan melarutkan $0,34 \mathrm{mg}$ glukosa dan $50 \mathrm{ml}$ aquades. Larutan anak dibuat menjadi 7 bagian dengan konsentrasi masingmasing adalah $0 \mathrm{mg} / \mathrm{dL}, 50 \mathrm{mg} / \mathrm{dL}, 100 \mathrm{mg} / \mathrm{dL}, 150 \mathrm{mg} / \mathrm{dL}, 200 \mathrm{mg} / \mathrm{dL}, 250$ $\mathrm{mg} / \mathrm{dL}$, dan $300 \mathrm{mg} / \mathrm{dL}$.

Pengujian sensitivitas sensor serat optik dilakukan sebagai berikut:sensor serat optik yang telah dikupas dicelupkan ke dalam larutan, variasi jari-jari bending yaitu $2,5 \mathrm{~cm}, 3,5 \mathrm{~cm}$, dan $4,5 \mathrm{~cm}$, lalu ukur tegangan keluaran fotodioda menggunakan multimeter, lalu diperoleh nilai tegangan keluaran sensor seperti yang terlihat pada Gambar 2.

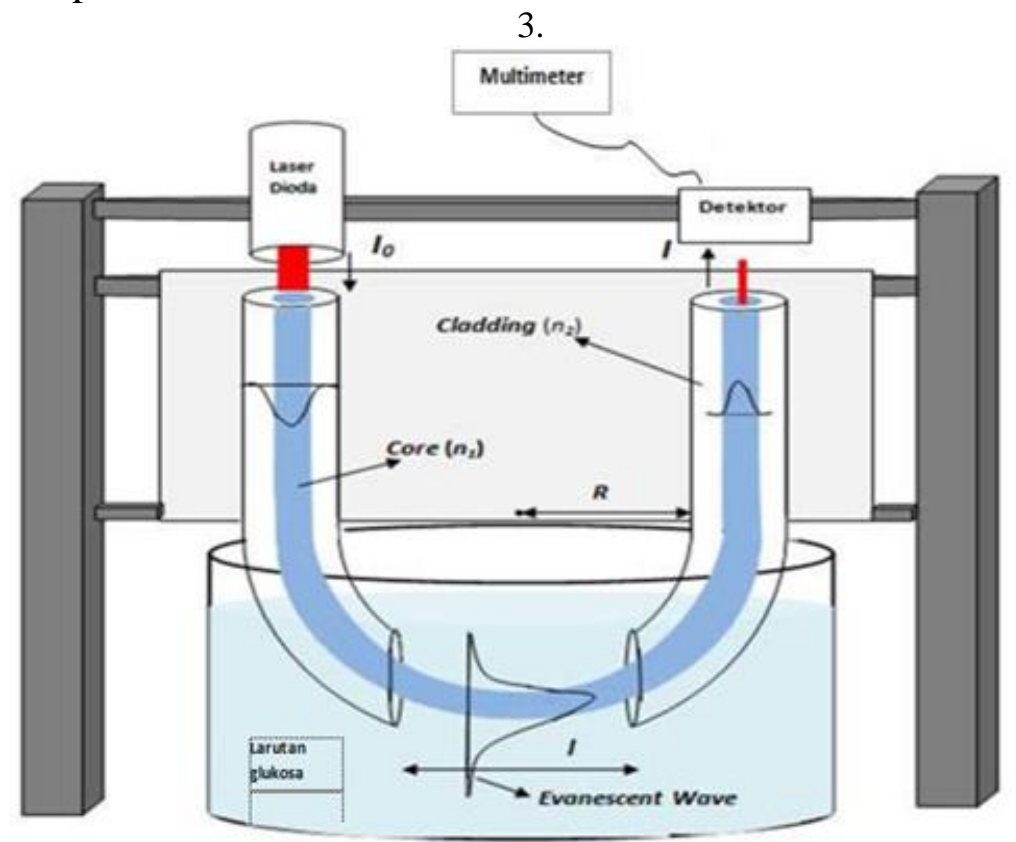

Gambar 2. Skema pengukuran kadar gula darah dengan menggunakan metode evanescent

Prinsip kerja serat optik sebagai sensor glukosa ini berdasarkan pada absorpsi gelombang evanescent pada antar muka core serat optik. Menurut Maddu (2007) perubahan nilai indeks bias cladding yang dimodifikasi akan menentukan intensitas gelombang evanescent yang terserap. Hal ini juga akan menentukan intensitas gelombang cahaya yang ditransmisikan di dalam core serat optik. Dengan kata lain, perubahan konsentrasi glukosa sebagai cladding akan menentukan gelombang evanescent yang terserap sehingga intensitas cahaya yang dideteksi fotodioda juga akan berubah.

\section{Kedalaman Penetrasi (Penetration Depth)}

Pada aplikasi sensor, penetration depth $(d)$ merupakan ukuran sensor untuk mengindera perubahan sekitar daerah yang diindera. Intensitas cahaya dalam arah z dapat ditulis sebagai (Purniawan, 2014): 
4.

$$
I_{z}=I_{z_{0}} \exp \left[-\frac{z}{d}\right]
$$

dimana $I_{z}$ adalah intensitas gelombang evanescent yang meluruh secara eksponensial terhadap jarak tegak lurus pada $z, z$ adalah arah dari permukaan dan $I_{z_{0}}$ adalah intensitas permukaan. Penetration depth dapat ditulis (Purniawan, 2014) :

$$
d=\frac{\pi}{4 \pi} \sqrt{n_{1}^{2} \sin ^{2} \theta_{1}-n_{2}^{2}}
$$

Dimana $d$ adalah penetration depth, $\lambda$ adalah panjang gelombang, $n_{l}$ adalah indeks bias medium pertama, dan $n_{2}$ adalah indeks bias medium kedua.

\section{HASIL DAN DISKUSI}

\subsection{Karakterisasi Sensor}

Sensor glukosa dikarakterisasi dengan melihat hubungan antara tegangan keluaran sensor dengan konsentrasi glukosa di dalam larutan. Plot data hasil karakterisasi dengan variasi jari-jari bending dapat dilihat pada Gambar 3. Data yang ditampilkan adalah nilai ratarata dan standar deviasi dari tiga pengukuran berulang.

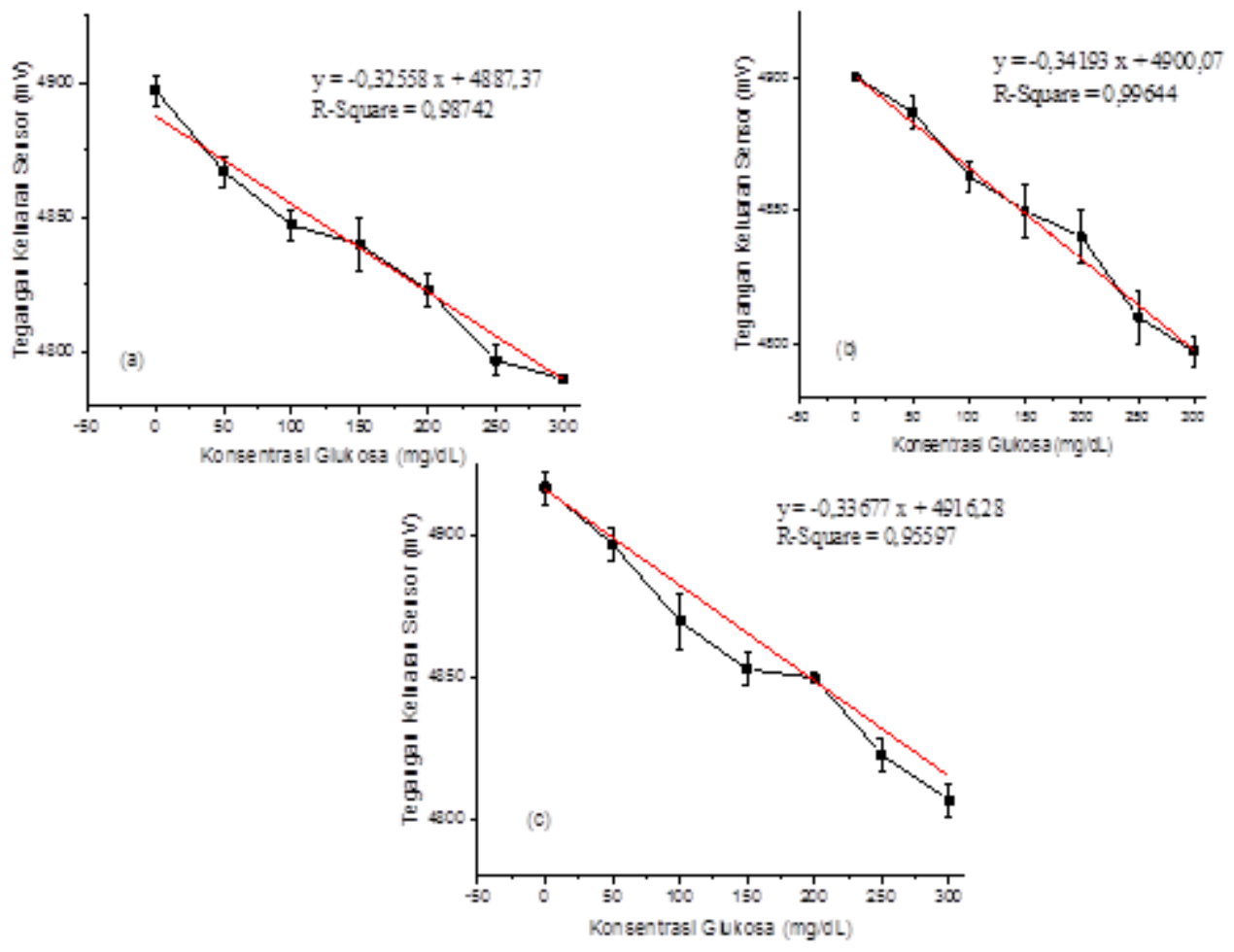

Gambar 3. Grafik hubungan tegangan keluaran sensor terhadap konsentrasi glukosa dengan variasi bending (a) $2,5 \mathrm{~cm}$, (b) $3,5 \mathrm{~cm}$, dan (c) $4,5 \mathrm{~cm}$

Tegangan keluaran sensor menurun dengan semakin tingginya konsentrasi glukosa, hal ini terjadi karena semakin tingginya konsentrasi glukosa, kedalaman penetrasi semakin rendah dan intensitas cahaya semakin tinggi sehingga tegangan fotodioda yang terukur semakin rendah. Tegangan keluaran sensor turun hampir linear dengan konsentrasi 
glukosa. Kecenderungan (trend) tegangan keluaran sensor dan konsentrasi glukosa menunjukkan sensitivitas, linearitas $\left(R^{2}\right)$ dan persamaan regresi linear.

\subsection{Data Hasil Analisis Karakterisasi}

Data hasil analisis dapat dilihat pada Tabel 1.

Tabel 1 Data hasil analisis karakterisasi sensor

\begin{tabular}{cccc}
\hline No. & Jari-Jari Bending $(\mathbf{c m})$ & $\begin{array}{c}\text { Sensitivitas Sensor } \\
((\mathbf{m g} / \mathbf{d L}) / \mathbf{m V})\end{array}$ & $\begin{array}{c}\text { Linearitas } \\
\text { Sensor }\end{array}$ \\
\hline 1. & 2,5 & 0,32558 & 0,98742 \\
2. & 3,5 & 0,34193 & 0,99644 \\
3. & 4,5 & 0,33677 & 0,95597 \\
\hline
\end{tabular}

Sensitivitas dan linearitas tertinggi yang diperoleh sensor berdasarkan hasil analisis grafik pada Gambar 3 adalah 0,34193 (mg/dL)/mVdan 0,99644 dimiliki sensor glukosa dengan jari-jari bending yaitu $3,5 \mathrm{~cm}$.


Gambar 4. Grafik hubungan jari-jari bending terhadap (a) sensitivitas sensor dan (b) linearitas sensor

Sensitivitas dan linearitas sensor menurun pada jari-jari bending $4,5 \mathrm{~cm}$ seperti yang dapat dilihat pada Gambar 4, hal ini terjadi karena terlalu rendahnya absorpsi glukosa oleh gelombang evanescent yang diakibatkan sangat sedikitnya radiation loss oleh sensor.

\section{KESIMPULAN}

Tegangan keluaran menurun dengan semakin meningkatnya konsentrasi glukosa. Sensitivitas meningkat pada jari-jari bending $3,5 \mathrm{~cm}$. Linearitas meningkat pada jari-jari bending $3,5 \mathrm{~cm}$. Semakin besarnya jari-jari bending maka intensitas cahaya semakin meningkat dan tegangan keluaran sensor juga semakin meningkat. 


\section{UCAPAN TERIMA KASIH}

Penulis mengucapkan terima kasih banyak kepada Fakultas MIPA Universitas Andalas yang telah mendanai penelitian ini dalam suatu kontrak penelitian/ mengadakan perjanjian pelaksanaan penugasan program penelitian skim riset dasar sesuai dengan kontrak Nomor: 35/UN.16.03.D/PP/FMIPA/2017.

\section{DAFTAR PUSTAKA}

1. America Diabetes Association, 2012, Diabetes Care, 35,1.

2. Bhumika, J.P. Bela, D. Dilip, D, Karmakar, P. Shah, M. dan Bhumi, S., 2015, Comparison and Correlation of Glucose Levels in Serum and Saliva of Both Diabetic and Non-Diabetic Patients, Journal of International OralHealth,78,70-76.

3. Binu, V.P. Mahadevan Pillai, V. Pradeep Kumar. Padhy, C.S. Joseph, N. Chandrase, K., 2008, Fiber Optic Glucose Sensor, Journal of Material Science and Engineering, 183-186.

4. Davies, N dan Shaw, DD., 2006, New Light Upon Non-Invasive Blood

5. Glucose Monitoring, Photonic Therapeutics and Diagnostic II, 6078, SPIE.

6. Irawati, N., 2012, Rancang Bangun Alat Pengukuran Kadar Gula Darah Menggunakan Metode Optik untuk PenderitaDiabetes Mellitus, Skripsi, UNAIR,

7. John, S., 2011, The Pursuit of Noninvasive Glucose: "Hunting The Deceitful Turkey", Ankara.

8. Kemenkes., 2014, Situasi dan Analisis Diabetes Mellitus, Pusat Data danInformasi Kementerian Kesehatan (INFODATIN).

9. Maddu, A., 2007, Pengembangan Sensor Serat Optik dengan Cladding Termodifikasi Polianilin Nanostruktur Untuk Mendeteksi Beberapa Uap Kimia, Disertasi, Program Pascasarjana Bidang Ilmu Teknik, Universitas Indonesia, Jakarta.

10. Ozaki, Y. Shinzawa, H. Maruo, K. Yi Ping Du. Kasemsumran, S, In Vivo Non Destructive Measurement of Blood Glucose By Near Infrared Diffuse Reflectance Spectroscopy Dalam Tuchin, V. Valery (2009), Handbook of Optical Sensing of Glucose in Biological Fluids and Tissues, Saratov State University and Institute Of Precise Mechanics and Control Of RAS Russia, 235-266.

11. Purniawan, A., 2014, Evanescent Waveguide Sensors for Biomedical Applications, Disertasi, Technischen Universitat Delft, Delft.

12. Said, K. Arend, L. Anike, S. Frangkie, M. Nora, L. Esther, M. Fahri, S. Charles, B. Marjes, T. dan Siti, S., 2016, Effects Of Gedi Leaves Stew on The Decrease of Blood Sugar Levels in Patients with Diabetes Mellitus, International Journal of Health Medicine And Current Research,1,01,40-45.

13. Sorvoja, H. dan Risto, M., 2006, Non- invasive Blood Pressure Measurement Methods, Optoelectronics and Measurement Techniques Laboratory,27, 239264. 